\title{
SLOVAKIANS' ADVERSARIAL ATTITUDE TOWARDS CONSUMPTION OF FUNCTIONAL FOOD
}

\author{
Pavol Mazalán1, Pavol Kita², Jaroslav Kita ${ }^{3}$, Marta Žambochová4, Jamal Hasan ${ }^{5}$, Augustín Prochotzký1 \\ ${ }^{12 n d ~ S u r g i c a l ~ C l i n i c, ~ F a c u l t y ~ o f ~ M e d i c i n e, ~ C o m e n i u s ~ U n i v e r s i t y ~ i n ~ B r a t i s l a v a, ~ B r a t i s l a v a, ~ S l o v a k ~ R e p u b l i c ~}$ \\ 2Department of Trade, Tourism and Languages, Faculty of Economics, University of South Bohemia in České Budějovice, České Budějovice, \\ Czech Republic \\ ${ }^{3}$ Department of Marketing, Faculty of Trade, University of Economics in Bratislava, Bratislava, Slovak Republic \\ ${ }^{4}$ Department of Mathematics and Management, Faculty of Social and Economic Studies, J. E. Purkyně University, Ústí nad Labem, Czech Republic \\ ${ }^{5}$ Department of Business IT, Faculty of Trade, University of Economics in Bratislava, Bratislava, Slovak Republic
}

\begin{abstract}
SUMMARY
Objectives: The aim of the article is to present the behaviour of Slovak consumers in terms of consumption in the field of functional food.

Methods: The survey was initiated in all regions of Slovakia. The sample involved 1,373 families which consisted of respondents aged 18-92 years. Friedman's test and subsequent post-hoc analysis were used to determine the reasons why people buy (or do not buy) a specific type of food. The survey deals with functional foods. Additionally, another classification method, namely a decision tree, was used.

Results: Decision trees help to identify factors influencing the choice of food by buyers. Based on this method, it can be stated that Slovak households still do not trust the functional foods bought in shops and are not interested in purchasing these foods.

Conclusion: In short, it could be assumed that the millennium generation would dominate households, and that they will probably prefer foods, in a higher degree of choice, as being pre-prepared foods. Therefore, food sales will move in this direction, although traditional patterns of behaviour, determined by the role of the mother in the family, still dominate. This trend can be reinforced by the lack of cooking skills and confidence among the younger generation, which will lead to reduced cooking and is considered barriers to healthy eating.
\end{abstract}

Key words: survey, decision-making of consumers, ecological, functional food

Address for correspondence: P. Mazalán, 2nd Surgical Clinic, Faculty of Medicine, Comenius University in Bratislava, Slovakia. E-mail: pavolmazalan@gmail.com

https://doi.org/10.21101/cejph.a6431

\section{INTRODUCTION}

Due to their benefits and because of the increasing importance of a healthy lifestyle, functional food products are becoming a part of consumers' everyday lives (1). Following the example of the Western world, the Slovak consumer has become exposed to unhealthy food cues (e.g., energy-dense food and the food itself) in shops, vending machines, and advertising. This omnipresence of unhealthy food cues is an acknowledged contributor to unhealthy eating (2). The attitude of society has also changed, not only determined by the determinants of ownership and access to food, but also by their quality, functionality, diversity, health benefits, and attractiveness. As a result of these transformations, a postmodern culture has developed, which has a significant impact on shaping the behaviour of today's consumers.

Thus far, most interventions have been aimed at changing the individuals' eating habits (e.g., diets and public health campaigns), and have not been particularly successful (3). Achieving the highest possible level of protection of the health and interests of customers is one of the fundamental objectives of the European Union. Improving the availability of healthy food is one of the principles of health policy. The existence and viability of a healthy food market depend on the attitude that consumers give to diet and health. Concerns about the health of individuals, although they have always existed, have increased in recent years among Slovak consumers.

It is now clear and proven that diet has a significant impact on health and improving the health of the population through BMI. BMI is used to assess obesity prevalence (BMI $>25 \mathrm{~kg} /$ $\mathrm{m}^{2}$ ). The BMI index for Slovakia in 2008 was $27.01 \mathrm{~kg} / \mathrm{m}^{2}(4)$. It has been observed that, according to the statistics of cardiac surgery in 2012 on a sample of 1,305 adult patients (including 407 women), the overall average BMI was $28.54 \mathrm{~kg} / \mathrm{m}^{2}$ (5). In 2018 , in a sample of 1,149 adult patients (including 335 women) the average BMI was $28.69 \mathrm{~kg} / \mathrm{m}^{2}$ (5). Consumers are changing their lifestyles, including changes in the structure of the consumed food quality enhancers they maintain, although the BMI tendency is increasing.

Regular consumption of healthy food is one of the tasks of changing consumer behaviour. A Slovak consumer declares the need to live in harmony with nature, and a vital element of this attitude is healthy eating. Consumers are increasingly aware of their needs, analysing the composition of the products they purchase, and being sceptical about trends in diet. Their knowledge of healthy eating may be superficial, but they are looking for reliable sources of product information. 
So forth, four groups of specific types of food were studied in the survey, these are organic food, functional food, ready-to-buy food, and home-cooked food. The authors of the paper focused on the presentation of empirical results in the field of consumption or non-consumption of functional foods belonging to the category of healthy eating. The specific food role is to create conditions for the optimal functioning of all human organs and to promote their defences. These kinds of food have a proven positive effect on the physical and/or mental health of a person and help to reduce the risk of various diseases. Functional foods represent an innovative category of foods that have a beneficial effect on human health and even cut and prevent disease. They have an added function, whether supportive, preventive, or curative and preventive - the term functional food is defined in different ways. There are also concepts in literature, such as dietetic foods and natural foods. The term "next-generation food", which includes genetically modified, low-protein, organic, and ethnic foods (6), may also be encountered. Szakály et al. (7) stated that the foods included in the functional food category are perceived by consumers to provide a beneficial effect on health, contain ingredients enriched or fortified by technological processes, and from which allergens and harmful components have been removed.

They also have a nutritional function, i.e., they are an integrated part of usual nutrition behaviour, and are not delivered through a tablet or capsule. Furthermore, they are foods that affect health when consumed in reasonable quantities.

Based on the above findings, we have formulated a research question on the consumption of functional food. We assume that consumers have a positive attitude towards functional foods concerning their health, according to Kita et al. (8) as a slope - the predisposition of the individual to respond to the subject in a favourable or in an unfavourable way. Also, attitude is the most reliable link, including the behaviour to functional food (9-11). Therefore, Patch et al. (11) considered attitude the only significant predictor of the intention to consume these foods. For example, Nystrand and Olsen (12) highlight nutrition and health knowledge and information; cognitive and sufficient antecedents such as attitudes, perceptions and beliefs, product properties, and socio-demographic variables as important for consumer choices regarding functional foods.

\section{MATERIALS AND METHODS}

\section{Study Population}

The survey was conducted from January-May 2019. The research used an intentional selection of 1,373 units of basic collection based on volunteering and availability to obtain the widest and most accurate information. The respondent's selection criteria did not take into account whether the respondent had food allergies or intolerances, not vegetarian or vegan, and of foods most liked. Pre-research on a sample of 200 respondents was carried out before the anonymous empirical research was conducted. During the pre-research phase, the comments of respondents dealing with the questionnaire structure were taken into account in the final adjustment. The questionnaire also contained questions related to respondents' general characteristics and their households with respect to motivation, perception and attitudes, preferences gener- ally influenced by education, employment, age, the financial situation in the household, residence, region, and if a man or woman made the household decisions. Empirical research was conducted in the form of personal interviews with each respondent.

\section{Data Analysis}

The article (13) deals with the investigation of preferences. The authors consider consumer preferences for one of the critical concepts of the analysis of their behaviour (13). We realize that only necessary, general demographic variables are not sufficient for proper segmentation. Therefore, we have extended these essential variables of variables information about specific purchases, especially the type of goods, characteristics of acquisition (length, date of purchase, etc.), satisfaction, or about the shortcomings of this purchase.

In addition to the variables describing the nature of the respondent, we mostly worked with ordinal variables. One type of these variables expressed the frequency (from never to every day), the other types were scale variables (values from -3 to 3 ). We used the IBM SPSS statistics version 22 for processing.

In the process, we first performed the following methods:

Friedman's test together with a post hoc analysis to determine reasons why people are (not) buying organic, functional and pre-made foods;

- non-parametric correlation analysis to determine the relationship between the observed factors;

- logistic regression to determine which factors affect consumers the most;

- cluster analysis for customer segmentation;

- decision trees to determine which factors affect consumers the most.

The selection of a suitable method is based on the types of variables, which contain the set of data (1,373 objects) that has been processed (nominal, ordinal, quantitative variables). In our case, we had at our disposal methods implemented in the statistical system SPPS specifically CRT (CART), CHAID, and QUEST. The method that best met our purposes was the two-step method (14). In the case of supervised learning, the deciding rules for classifying the objects are based on a training aggregate. The representative of this group method is a decision tree (15). All these algorithms were used and then the best one was chosen.

\section{RESULTS}

Respondents' age ranged from 18 to 92 years (median 38.00, standard deviation 17.20, average 40.33); 741 women (53.97\%) and 632 men (46.03\%) participating in the research were divided into the following generations (16):

- generation Z - 350 (24.54\%) respondents, or the internet generation, born after 2000; in 2019, the age span was 0 to 19 years of age (17). The lowest age group was represented by the age of 17, with respect to the fact that the Slovak statistical institute considers a young person from 17 to 29 years of age;

- generation Y - 287 (20.83\%) respondents, or the millennials, born between 1981 and 1999; in 2019, the age span was 20 to 38 years of age $(18,19)$; 
- generation X-439(32.99\%) respondents, born between 1966 and 1980; in 2019, the age span was 39 to 53 years of age (20);

- baby-boom generation - 127 (9.25\%) respondents, born between 1946 and 1965; in 2019, the age span was 54 to 73 years of age (21);

- the silent generation - $170(12.38 \%)$ respondents, born in the years 1930-1945; in 2019, the age span was 74 years of age and above (21).

The structure of families in this survey indicates that the trend of more families with one or two persons (cumulatively $66.57 \%$ ) dominated over traditional families with one or more children $(33.43 \%)$. Families that were deployed in small towns represented $34.38 \%$, while in large cities over 201,000 inhabitants, the share of respondents was $25.3 \%$. Respondents accounting for more than $3 \%$ of families were experienced and without a lack of finances, almost $66.74 \%$ of families were well or very well financially secure. $50.4 \%$ of female respondents, who have a decisive role in the household when buying food, completed secondary education; $40 \%$ of women completed university education; only $1.8 \%$ completed primary school; and $7.6 \%$ of women had apprenticeships. Table 1 shows individual respondents eating irregularly, the basic courses of meals such as breakfast, brunch, lunch, tea time (mid-afternoon snack), and dinner on weekdays and public holidays were compared.

Table 1 shows that there is a time shift, for example, when eating food on business days and then on weekdays. Alarming is the condition of people who do not regularly consume a certain meal throughout the week. This issue indicates that there are people who do not feel hungry due to stress from their state of workload. As for the non-breakfast respondents, they may not feel hungry due to the late dinner of the previous day. It also shows that consumers eat more regularly on weekdays than on the weekend.

We were also interested in whether individual age categories differ for the level of consumption of different types of functional food (Table 2). For this purpose, we repeatedly used the nonparametric Kruskal-Wallis test to compare several independent selections. The results of the individual tests are shown in Table 2. Food types that have statistically significant differences in opinions on the level of consumption are marked with asterisks. In the remaining cases, no differences were found. This process applies to dairy products, fruits, vegetables, meat products, eggs, non-alcoholic unsweetened products, and coffee.

Food types, for statistically significant differences that we demonstrated post-hoc by Tukey HSD, were based on the possible verified following findings. For pastries, both extreme age categories have an above-average consumption, those who are younger than 24 years and older than 65 years. The remaining three types have a similar use, which is lower compared to the first two.

The age category $\mathrm{Z}$ differs from the other categories by a higher consumption of fish and also of seafood. In the consumption of sugar and sweets, the age category $\mathrm{Z}$ differs by its higher use and in the category $\mathrm{Y}$ by its lower consumption compared to other

Table 1. Comparison of eating meals

\begin{tabular}{|c|c|c|}
\hline & Business day & Weekend (day off) \\
\hline Breakfast & $\begin{array}{l}136 \text { respondents do not have breakfast on business days. } \\
\text { The first respondent has breakfast at 03:20, as does the last } \\
\text { one at 11:00 a.m. } \\
\text { Most respondents have breakfast at about 7:00 a.m. } \\
\text { Average mid-morning snack time is 7:11 a.m. }\end{array}$ & $\begin{array}{l}77 \text { respondents do not have breakfast on days off. } \\
\text { The first respondent has breakfast at 3:20 a.m., as does the } \\
\text { last one at 1:30 p.m. } \\
\text { Most respondents have breakfast between 8:00-9:00 a.m. } \\
\text { Average breakfast time is 8:32 a.m. }\end{array}$ \\
\hline Mid-morning snack & $\begin{array}{l}529 \text { respondents do not have a mid-morning snack on busi- } \\
\text { ness days. } \\
\text { The first respondent has a mid-morning snack at 7:00 a.m., as } \\
\text { does the last one at 1:30 p.m. } \\
\text { Most respondents have a mid-morning snack at about 10:00 } \\
\text { a.m. } \\
\text { Average mid-morning snack time is } 9: 55 \text { a.m. }\end{array}$ & $\begin{array}{l}774 \text { respondents do not have a mid-morning snack on days } \\
\text { off. } \\
\text { The first respondent has a mid-morning snack at 7:00 a.m., as } \\
\text { does the last one at 3:00 p.m. } \\
\text { Most respondents have a mid-morning snack at about 10:00 } \\
\text { a.m. } \\
\text { Average mid-morning snack time is 10:26 a.m. }\end{array}$ \\
\hline Lunch & $\begin{array}{l}20 \text { respondents do not have lunch on business days. } \\
\text { The first respondent has lunch at 10:30 a.m., as does the last } \\
\text { one at 4:00 p.m. } \\
\text { Most respondents have lunch between noon-1:00 p.m. } \\
\text { Average lunchtime is 12:23 p.m. }\end{array}$ & $\begin{array}{l}19 \text { respondents do not have lunch on days off. } \\
\text { The first respondent has lunch at 11:00 a.m., as does the last } \\
\text { one at 7:00 p.m. } \\
\text { Most respondents have lunch between noon-01:00 p.m. } \\
\text { Average lunchtime is 12:45 p.m. }\end{array}$ \\
\hline Mid-afternoon snack & $\begin{array}{l}532 \text { respondents do not have a mid-afternoon snack on busi- } \\
\text { ness days. } \\
\text { The first respondent has a mid-afternoon snack at noon, as } \\
\text { does the last one at 7:00 p.m. } \\
\text { Most respondents have a mid-afternoon snack between } \\
\text { 3:00-4:00 p.m. } \\
\text { Average mid-afternoon snack time is } 3: 32 \text { p.m. }\end{array}$ & $\begin{array}{l}555 \text { respondents do not have a mid-afternoon snack on days } \\
\text { off. } \\
\text { The first respondent has a mid-afternoon snack at 10:00 a.m., } \\
\text { as does the last one at 8:00 p.m. } \\
\text { Most respondents have mid-afternoon snack between } \\
\text { 3:00-4:00 p.m. } \\
\text { Average mid-afternoon snack time is 3:48 p.m. }\end{array}$ \\
\hline Dinner & $\begin{array}{l}41 \text { respondents do not have dinner on business days. } \\
\text { The first respondent has dinner at 3:00 p.m., as does the last } \\
\text { one at 10:30 p.m. } \\
\text { Most respondents have dinner between 6:00-7:00 p.m. } \\
\text { Average dinner time is 6:30 p.m. }\end{array}$ & $\begin{array}{l}41 \text { respondents do not have dinner on days off. } \\
\text { The first respondent has dinner at 4:00 p.m., as does the last } \\
\text { one at 11:00 p.m. } \\
\text { Most respondents have dinner between 6:00-7:00 p.m. } \\
\text { Average dinner time is 6:44 p.m. }\end{array}$ \\
\hline
\end{tabular}


categories. The consumption of legumes increases with age, i.e., the age category $\mathrm{Z}$ has significantly lower consumption and, on the contrary, people over 65 have a much higher use. Surprisingly, a similar situation is in the consumption of vegetable and animal fats, but also nuts.

The situation is different in the case of sweetened soft drinks. Here, the age category $\mathrm{X}$ shows the highest consumption. The Y-category also has a higher use compared to the other three categories but lags significantly behind the X-category.

In the analysis of the use of gastronomic facilities, we elaborated on the relationship between individual types of facilities (Table 3). Variables related to different types of catering facilities reflect the intensity of use of the given type (values 1-4). For this purpose, we used a nonparametric correlation, especially the Spearman's coefficient. The coefficients between the different types of services are shown in Table 3. All factors are significant at the $1 \%$ significance level. This paper compares the most stable relationship between pubs and bars, the bars and cafés, and the cafés and restaurants. On the contrary, the lowest correlation was found among the canteens and other types of assistance.

Besides, we verified (using the Friedman test and subsequent post hoc analysis) that consumers as a whole visit, for the most, restaurants and then cafés. On the contrary, they use catering services the least.

In a further analysis, we segmented consumers in terms of how often they use catering services. For this purpose, we performed cluster analysis, especially the Two Step method using Euclidean distance. Clusters formed three clusters, the first of which contained $29.7 \%$ of respondents, the second $26.1 \%$, and the third $44.2 \%$. The resulting clustering quality was excellent; the silhouette coefficient value was 0.3 .

The research by Robson et al. (22) confirms that consumers prefer convenience foods or foods prepared from home, as these foods are more calorically dense, of a more inferior nutritional quality, as they tend to be higher in saturated fat, sodium, and cholesterol, and lower in calcium and dietary fibre, when compared

Table 2. Consumption of types of functional food

\begin{tabular}{|c|c|c|}
\hline & Chi-Square & $p$-value \\
\hline Milk and dairy products & 6.179 & 0.186 \\
\hline Pastries and other bakery products & 20.536 & $<0.001^{* * *}$ \\
\hline Vegetables & 3.226 & 0.521 \\
\hline Fruit & 5.775 & 0.217 \\
\hline Meat and meat products & 8.776 & 0.067 \\
\hline Fish and fish products & 11.137 & $0.025^{*}$ \\
\hline Seafood & 9.919 & $0.042^{*}$ \\
\hline Sugar and candies & 17.493 & $0.002^{* *}$ \\
\hline Eggs & 3.620 & 0.460 \\
\hline Legumes & 32.085 & $<0.001^{* * *}$ \\
\hline Vegetable fats & 13.363 & $0.010^{* *}$ \\
\hline Animal fats & 19.015 & $0.001^{* * *}$ \\
\hline Nuts & 22.080 & $<0.001^{* * *}$ \\
\hline Non-alcoholic beverages unsweetened (e.g., mineral waters, spring waters) & 4.586 & 0.332 \\
\hline Non-alcoholic beverages sweetened (e.g., flavoured waters, carbonated drinks) & 21.656 & $<0.001^{* * *}$ \\
\hline Coffee & 6.143 & 0.189 \\
\hline Tea & 10.210 & $0.037^{*}$ \\
\hline
\end{tabular}

${ }^{*}$ significant at $p<0.05 ;{ }^{* *}$ significant at $p<0.01 ;{ }^{* * *}$ significant at $p<0.001$

Table 3. Correlation among facility types where consumers eat meals

\begin{tabular}{|l|c|c|c|c|c|c|c|c|}
\hline & Restaurants & Cafés & Bars & Pubs & Pizzerias & Fast food & Dining halls & Catering \\
\hline Restaurants & 1.000 & $0.645^{* *}$ & $0.550^{* *}$ & $0.382^{* *}$ & $0.470^{* *}$ & $0.425^{* *}$ & $0.172^{* *}$ & $0.246^{* *}$ \\
\hline Cafés & $0.645^{* *}$ & 1.000 & $0.626^{* *}$ & $0.404^{* *}$ & $0.480^{* *}$ & $0.406^{* *}$ & $0.181^{* *}$ & $0.260^{* *}$ \\
\hline Bars & $0.550^{* *}$ & $0.626^{* *}$ & 1.000 & $0.686^{* *}$ & $0.509^{* *}$ & $0.486^{* *}$ & $0.253^{* *}$ & $0.284^{* *}$ \\
\hline Pubs & $0.382^{* *}$ & $0.404^{* *}$ & $0.686^{* *}$ & 1.000 & $0.434^{* *}$ & $0.424^{* *}$ & $0.288^{* *}$ & $0.301^{* *}$ \\
\hline Pizzerias & $0.470^{* *}$ & $0.480^{* *}$ & $0.509^{* *}$ & $0.434^{* *}$ & 1.000 & $0.545^{* *}$ & $0.226^{* *}$ & $0.222^{* *}$ \\
\hline Fast food & $0.425^{* *}$ & $0.406^{* *}$ & $0.486^{* *}$ & $0.424^{* *}$ & $0.545^{* *}$ & 1.000 & $0.284^{* *}$ & $0.245^{* *}$ \\
\hline Dining halls & $0.172^{* *}$ & $0.181^{* *}$ & $0.253^{* *}$ & $0.288^{* *}$ & $0.226^{* *}$ & $0.284^{* *}$ & 1.000 & $0.218^{* *}$ \\
\hline Catering & $0.246^{* *}$ & $0.260^{* *}$ & $0.284^{* *}$ & $0.301^{* *}$ & $0.222^{* *}$ & $0.245^{* *}$ & $0.218^{* *}$ & 1.000 \\
\hline
\end{tabular}

${ }^{* *}$ Correlation is significant at 0.01 level (2-tailed). 
to foods prepared at home, and often are more significant than the recommended portion. Subsequently, we constructed several classification trees using both opinions and identification (sociodemographic) data. In one variant, we chose socio-demographic questions as the explanatory variables, and in the second group, we chose questions expressing the opinion on the consumption of foodstuffs of interest. In both cases, we chose the cluster variable as a dependent variable. We have always created trees using the CRT, CHAID, and QUEST algorithms and selected the tree with the least risk estimate. A top-quality tree is shown in Figure 1. Cluster's socio-demographic characteristics and opinion characteristics are described in Table 4.

It is clear from the above data that the most important factor influencing consumer behaviour in terms of how often they use gastronomic services is age. It can be said that the younger the consumers, the higher the intensity of visits to gastronomic establishments. It is noted that the younger consumers benefit from a broader range of gastronomic facilities. Also, research by Steptoe et al. shows that food choice motivations predict differences in actual food choices, and mediate socioeconomic disputes in food choices (23).
The almost zero p-values of Friedman's test pointed out that there were very significant differences between the factors. Subsequent post-hoc analysis revealed that most consumers felt the factor "This type of food is too expensive." Somewhat weaker were the factors "I am not interested in buying these foods" and "In the shop where I buy such types of food, they do not have it." The least important factors were "Stores with this kind of food are too far from my home" and "I do not trust this kind of food."

In the next step of the analysis, we used the nonparametric correlation analysis. All calculated Spearman's correlation coefficients were statistically significant (Table 5).

It was found that the frequency of purchase of functional foods is mostly correlated with the factor "I am not interested in buying these foods." Furthermore, it was identified that the mostly correlated factors are "I do not want to buy these foods" and "I do not trust this kind of food." Somewhat less correlated are the factors "In the store where I buy this type of food, they do not have it" and "Stores with this kind of food are too far away from my home." The weakest relationship with other factors is shown by the factor "This type of food is too expensive" which correlates slightly with the factor "In the shop where I buy such

Table 4. Clusters of consumers by social and economic characteristics

\begin{tabular}{|l|l|l|}
\hline & Socio-demographic characteristics & Opinion characteristics \\
\hline Cluster 1 & $\begin{array}{l}\text { Aged } 65 \text { and over; silent generation (current pensioners) } \\
\text { More in the Trenčin, Nitra, Prešov regions }\end{array}$ & $\begin{array}{l}\text { People who visit cafés occasionally, as to those who visit dining } \\
\text { halls, they do not use catering at all. }\end{array}$ \\
\hline Cluster 2 & $\begin{array}{l}\text { 35-56 years generation } \\
\text { Banská Bystrica, Bratislava, Žilina regions } \\
\text { In the remaining region's (women) }\end{array}$ & $\begin{array}{l}\text { People who visit cafés occasionally, they use dining halls at least } \\
\text { twice a month. } \\
\text { People who visit cafés at least twice a month, they visit bars some- } \\
\text { times, they visit restaurants occasionally. }\end{array}$ \\
\hline \multirow{2}{*}{ Cluster 3 } & $\begin{array}{l}\text { Young people aged up to 35 } \\
\text { More in the Banská Bystrica, Bratislava, Trenčín, Trnava, Košice } \\
\text { regions }\end{array}$ & $\begin{array}{l}\text { People who visit cafés at least twice a month, as they do bars. } \\
\text { People who visit cafés at least twice a month, they visit bars oc- } \\
\text { casionally, they visit restaurants at least twice a month. }\end{array}$ \\
\hline
\end{tabular}

Table 5. Correlations in functional foods

\begin{tabular}{|l|c|c|c|c|c|c|}
\hline & Functional foods & $\begin{array}{c}\text { The store } \\
\text { in which the client } \\
\text { shops does not } \\
\text { carry these types } \\
\text { of foods }\end{array}$ & $\begin{array}{c}\text { These types } \\
\text { of food are too } \\
\text { expensive }\end{array}$ & $\begin{array}{c}\text { I am not interested } \\
\text { in shopping for } \\
\text { these foods }\end{array}$ & $\begin{array}{c}\text { Stores with these } \\
\text { I do not trust these } \\
\text { types of foods are } \\
\text { too far away from } \\
\text { my dwelling place }\end{array}$ \\
\hline Functional foods & 1.000 & $0.118^{* *}$ & $0.100^{* *}$ & $0.325^{* *}$ & $0.254^{* *}$ & $0.130^{* *}$ \\
\hline $\begin{array}{l}\text { The store in which } \\
\text { I shop at does not } \\
\text { carry these types of } \\
\text { foods }\end{array}$ & $0.118^{* *}$ & 1.000 & $0.242^{* *}$ & $0.286^{* *}$ & $0.258^{* *}$ & $0.409^{* *}$ \\
\hline $\begin{array}{l}\text { These types of food } \\
\text { are too expensive }\end{array}$ & $0.100^{* *}$ & $0.242^{* *}$ & 1.000 & $0.175^{* *}$ & $0.184^{* *}$ & $0.228^{* *}$ \\
\hline $\begin{array}{l}\text { I am not interested } \\
\text { in shopping for } \\
\text { these foods }\end{array}$ & $0.325^{* *}$ & $0.286^{* *}$ & $0.175^{* *}$ & 1.000 & $0.594^{* *}$ & $0.287^{* *}$ \\
\hline $\begin{array}{l}\text { I do not trust these } \\
\text { types of food }\end{array}$ & $0.254^{* *}$ & $0.258^{* *}$ & $0.184^{* *}$ & $0.594^{* *}$ & 1.000 & $0.312^{* *}$ \\
\hline $\begin{array}{l}\text { Stores with these } \\
\text { types of foods are } \\
\text { too far away from } \\
\text { my dwelling place }\end{array}$ & $0.130^{* *}$ & $0.409^{* *}$ & $0.228^{* *}$ & $0.287^{* *}$ & $0.312^{* *}$ & 1.000 \\
\hline
\end{tabular}

** Correlation is significant at 0.01 level (2-tailed). 
types of food, they do not have it" and "Stores with this kind of food are too far from my home."

We were also interested in how the individual monitored factors influence the frequency of consumption of functional foods. For this purpose, we primarily used the method of logistic regression, especially its ordinal variant. The frequency of consumption of functional foods (from never to every day) is a dependent variable. The factors mentioned in Table 5 are independent variables. In the previous analysis, there was no strong correlation between factors, so logistic regression is applicable. The elements "I am not interested in buying these foods" and "I do not trust this kind of food" proved to be statistically significant at the 5\% level of significance. As for other factors they have not been found substantial. The resulting significance $p$-value of the $<0.001$ model indicates that the resulting model is significant. We can interpret the resulting model coefficients.

By recalculating the chances (using the exponential function), we get information that when the importance of the "I am not interested in buying these foods" factor increases by one degree, the chances of shifting the consumption frequency scale by 1.33 times becomes $33 \%$. Increasing the importance of the factor " $\mathrm{Cli}$ ent does not trust this type of food" by one degree will increase the chances of shifting the consumption frequency scale by almost 1.13 times, i.e., by $13 \%$. It should be stressed that the level of consumption frequency is decreasing, so the rate is "Every day", and the highest is "Never". This method also determined the factor "I am not interested in buying these foods" as the strongest. Furthermore, the second significant factor again identified the factor "I do not trust this kind of food". The result thus corresponds with the outcome of logistic regression.

With the same goal, we used another classification method, decision trees. We constructed a decision tree using three algo- rithms (CHAID, CRT and QUEST) and selected the best quality according to the risk estimate. In all three cases, we chose the frequency of consumption of pre-prepared foods as the described variable and all factors explaining the reasons why the client does not use the grains as explanatory variables.

The CRT algorithm showed the best quality, but the variety of all the trees was very similar. All the trees revealed as being the most critical factor "I am not interested in buying these foods." The QUEST algorithm even evaluated this factor as the only important one. The CHAID algorithm then considered the elements "Shops with this food trench too far from client home" and "At the store where I shop for this type of groceries" not necessary. The CRT algorithm evaluated the remaining four factors as equally important. Figure 1 shows a tree created using the CHAID algorithm.

\section{DISCUSSION}

The scientific community and the public are now more interested in natural products to maintain consumer health. These client categories demand and reflect the ever-growing market for functional food products containing health-promoting ingredients or bacteria $(24,25)$. This trend is already evident in the European Union. In Western European countries, organic food expenditure is the highest. Consumers in these countries spend more than $100 €$ per year on organic food. The highest annual per capita consumption has been recorded in Switzerland (177€), followed by Denmark (162€), Luxembourg (134 €), Austria (127€), and Liechtenstein $(100 €)$. Central and Eastern European countries have the smallest share of organic food consumption in Europe. The most significant retail sales of natural products account for

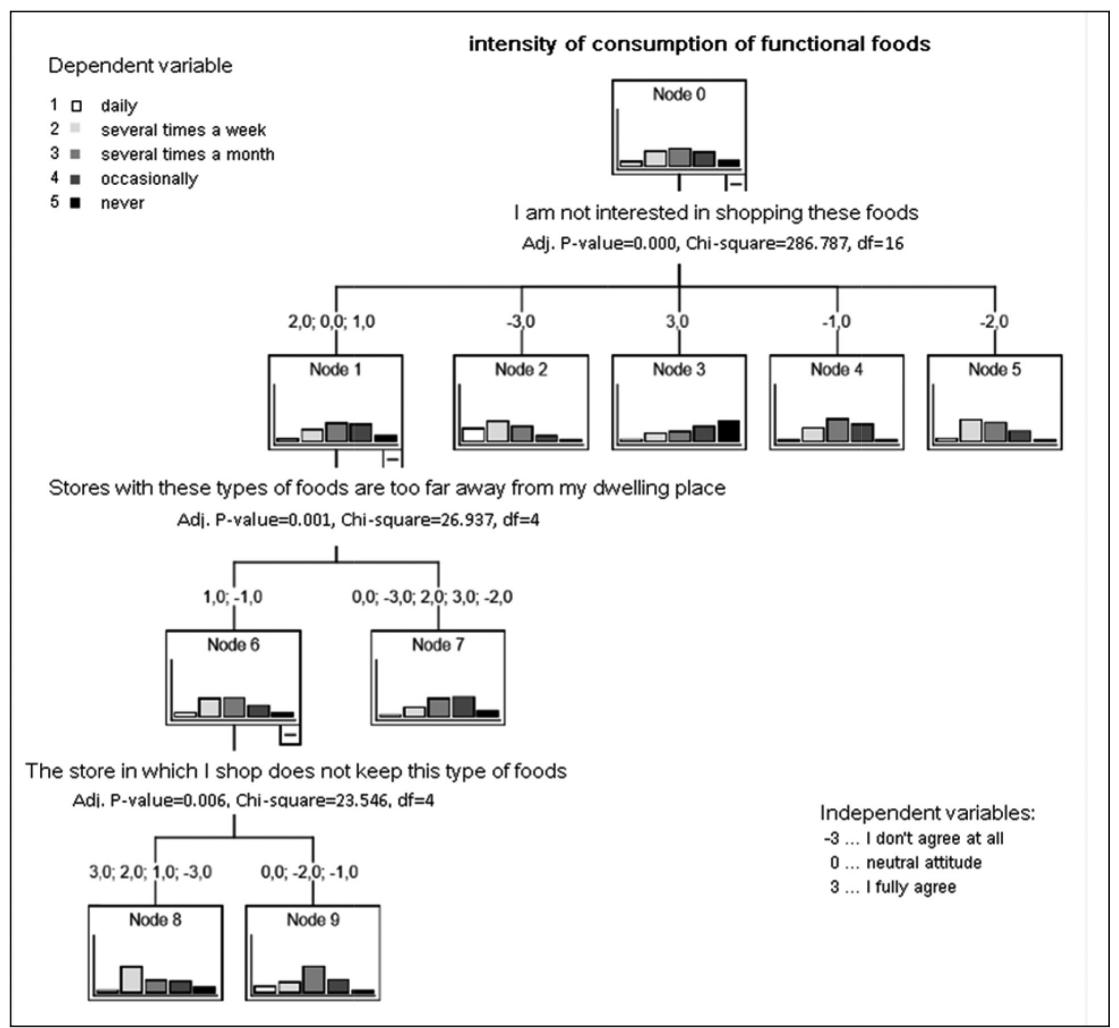

Fig. 1. Consumer decision-making model concerning functional foods. 
$47 \%$ of global sales. The European Union accounts for 36\% (5). In recent years, the European Union has invested 3.3 billion $€$ in safe food policy, with a budget of 2.2 billion $€$ in 2014-2020.

Shopping centres, which use quality food as an attraction, are also responding to this trend, as consumers can invest part of it in the growth of living standards due to income growth. Its availability is almost everywhere, but it depends on what kind of food it is.

The present study demonstrated that Slovak consumers prefer three main courses during the day and also postpone dinner time. Both facts can have adverse health effects as to the suitability of eating habits. In terms of their consumption of healthy food, all ages consistently consume white bread and bakery products. Differences arise with age. The results show that the most youthful generation is in the age of group $\mathrm{Y}$ and over 65 years.

One can observe the differences in food consumption in the $\mathrm{Z}$ generation. On one hand, they consume more fish and seafood, which is related to new trends in healthy eating, but on the other hand, they do not eat many legumes and also consume many sweets. Another relatively young group of consumers is group X, which destroys their health by many sweets, i.e., sweet drinks. Their consumption suggests that these people need much energy in their work, and it may be related to their stress at work. This may be based on their use, their behaviour, and attitude to health as could be identified. Paradoxically, it turns out that neither age category consumes eggs, fruit, vegetables, meat and meat products, or coffee to a significant extent. This age level means that consumers may prefer other types of food based on the choice of a store offer on the site.

Within the food domain, the attitude often shares the strongest association with the intention $(21,26,27)$, including behaviour towards functional food $(9,11)$. In their study of functional foods, Patch et al. (11) found the attitude to be the only significant predictor of intention to consume. Along the same lines, Hung et al. (9) demonstrated that mentality was the most crucial determinant of the purchasing purpose of a new functional meat product. This approach also implies the frequency of consumption of healthy functional foods. Generally, consumers are not interested in, nor are they looking for stores with this specific type of food. The purchasing decision model suggests that they only buy foods that are offered by the nearest store that they choose. Their buying behaviour is an attitude oriented only to the hedonistic characteristics of food, which is a carefree search and quick availability of food, along with fast food preparation. Overall, however, it can be assumed that in the short future, households will be dominated with the millennium generation, and they will probably prefer foods with a higher degree of cooking. Therefore, food sales will move in this direction, although traditional patterns of behaviour determined by the role of the mother in the family still dominate. This trend, reinforced by the lack of cooking skills and confidence among the younger generation, will lead to reduced cooking and is considered barrier to healthful eating.

\section{CONCLUSION}

The decision tree method helps to identify factors influencing the choice of food by buyers. Based on this method, it was stated that Slovak households still do not trust the functional foods bought in the shop and are not interested in purchasing these foods.
Despite certain limitations, the present study offers an explicit demonstration of the wrong attitude to healthy food in the context of food choice. Consumers consume hazardous allergic foods such as chocolate, seafood, and the like. They also do not eat at rest, which suggests at an "eating time", they forfeit the reasons as to why they are not looking for stores offering functional foods. As a result, they will increasingly focus on pre-prepared food. It is mainly the young generation. Older people eat quite healthily. The benefits of the paper are both theoretical and practical. Theoretically, the results provide support for promoting healthy eating. At a reasonable level, the results have implications for the design of outlets. Accordingly, the present study provides an important starting point for future research aimed at informing strategies to promote healthy food choices.

\section{Acknowledgement}

This work was supported by the Slovak Agency for Research and Development under contract no. APVV-16-0232. VEGA 1/0066/18 Model of Marketing Communication on Health-Oriented Consumer Shopping Behaviour

\section{REFERENCES}

1. Plasek B, Temesi A. The credibility of the effects of functional food products and consumers' willingness to purchase/willingness to pay- review. Appetite. 2019;143:104398. doi: 10.1016/j.appet.2019.104398.

2. Novak NL, Brownell KD. Role of policy and government in the obesity epidemic. Circulation. 2012;126(19):2345-52.

3. Keegan E, Kemps E, Prichard I, Polivy J, Hermanc CP, Tiggemann M. The effect of the spatial positioning of a healthy food cue on food choice from a pictorial-style menu. Eat Behav. 2019;34:101313. doi: 10.1016/j. eatbeh.2019.101313.

4. Nichols M, Townsend N, Luengo-Fernandez R, Leal J, Gray A, Scarborough P, et al. European Cardiovascular Disease Statistics 2012. Brussels: European Heart Network; 2012.

5. National Health Information Center. Official demand NCZI-00221-2020 BMI dataset to providing information from 21 st February 2020. Bratislava: NHIC; 2020.

6. Dabrowska A, Babicz-Zieliňska E. Consumers' behaviors with reference to novel food. Hygea Public Health. 2011;46(1):39-46.

7. Szakály Z, Kovács S, Pető K, Huszka P, Kiss M. A modified model of the willingness to pay for functional foods. Appetite. 2019;138:94-101.

8. Kita J, et al. Marketing. Bratislava: Wolters Kluwer; 2017.

9. Hung Y, de Kok TM, Verbeke W. Consumer attitude and purchase intention towards processed meat products with natural compounds and a reduced level of nitrite. Meat Sci. 2016;121:119-26.

10. O'Connor EL, White KM. Willingness to trial functional foods and vitamin supplements: The role of attitudes, subjective norms, and dread of risks. Food Qual Prefer. 2010;21(1):75-81.

11. Patch CS, Tapsell LC, Williams PG. Overweight consumers' salient beliefs on omega-3-enriched functional foods in Australia's Illawarra region. J Nutr Educ Behav. 2005;37(2):83-9.

12. Nystrand BT, Olsen SO. Consumers' attitudes and intentions toward consuming functional foods in Norway. Food Qual Prefer. 2020;80:103827. doi: 10.1016/j.foodqual.2019.103827.

13. Vojáček O. Preference dilemma in economics. Politická ekonomie. 2011;59(3):345-58. (In Czech.)

14. Grossmanová M, Kita P, Žambochová M. Segmentation of consumers in the context of their space behaviour: case study of Bratislava. Prague Econ Pap. 2016;25(2):189-202.

15. Žambochová M. Data mining methods with trees. E\&M Econ Manag. 2008;2008(1):126-31.

16. Miller RK, Washington K. Consumer behavior 2011. Loganville: Richard K. Miller \& Associates; 2011.

17. Williams KC, Page RA, Petrosky AR, Hernandez EH. Multi-generational marketing: descriptions, characteristics, lifestyles, and attitudes. J Appl Bus Econ. 2010;11(2):21-36. 
18. Bolton RN, Parasuraman A, Hoefnagels A, Migchels N, Kabadayi S, Gruber T, et al. Understanding Generation Y and their use of social media: a review and research agenda. J Serv Manag. 2013;24(3):245-67.

19. Foscht T, Schloffer J, Maloles C, Chia SL. Assessing the outcomes of Generation-Y customers' loyalty. Int J Bank Mark. 2009;27(3):218-41.

20. Brosdahl DJ, Carpenter JM. Shopping orientations of US males: a generational cohort comparison. J Retailing Consum Serv. 2011;18(6):548-54.

21. Maciejewski G. Consumers' attitudes towards modern solutions in the retail trade. Econ Bus Rev. 2018;4(3):69-85

22. Robson SM, Stough CO, Stark LJ. The impact of a pilot cooking intervention for parent-child dyads on the consumption of foods prepared away from home. Appetite. 2016;99:177-84

23. Steptoe A, Pollard TM, Wardle J. Development of a measure of the motives underlying the selection of food: the food choice questionnaire. Appetite. 1995;25(3):267-84.

24. Douillard FP, de Vos WM. Biotechnology of health-promoting bacteria. Biotechnol Adv. 2019;37(6):107369. doi: 10.1016/j.biotechadv.2019.03.008.
25. Vicentini A, Liberatore L, Mastrocola D. Functional foods: trends and development of the global market. Ital J Food Sci. 2016;28(2):338-51.

26. McDermott MS, Oliver M, Simnadis T, Beck E, Coltman T, Iverson D, et al. The theory of planned behaviour and dietary patterns: a systematic review and meta-analysis. Prev Med. 2015;81:150-6.

27. Povey R, Conner M, Sparks P, James R, Shepherd R. The theory of planned behaviour and healthy eating: examining additive and moderating effects of social influence variables. Psychol Health. 2000;14(6):9911006.

Received July 6, 2020 Accepted in revised form May 7, 2021 